\title{
Scrotal migration of ventriculoperitoneal shunt
}

\author{
Balasubramanyam Shankar, Ramakrishna Narayanan, Samir Mustaffa Paruthikunnan, \\ Chaitanya Dattatray Kulkarni
}

Department of Radiodiagnosis, Kasturba Medical College, Manipal, Karnataka, India

\section{Correspondence to} Dr Balasubramanyam Shankar, balabhaimbbs@gmail.com

Accepted 13 March 2014

\section{- -}

To cite: Shankar $B$,

Narayanan R,

Paruthikunnan SM, et al. BMJ Case Rep Published

online: [please include Day

Month Year] doi:10.1136/

bcr-2014-204404

\section{DESCRIPTION}

A 1-year-old male child with type II Chiari malformation who underwent ventriculoperitoneal (VP) shunt placement 11 months ago presented with right scrotal swelling.

Frontal radiograph of the chest and abdomen (figure 1) showed the shunt tube in the abdomen which was twisted and kinked in its mid portion and its distal end coiled in the right scrotum.

Surgical exploration revealed bilateral patent processus vaginalis through which the VP shunt had migrated into the right scrotum. Repositioning of the shunt and repair of the bilateral hernia was performed to prevent further complications and malfunctioning of the shunt.

VP shunt commonly used to treat hydrocephalus is associated with numerous complications, which

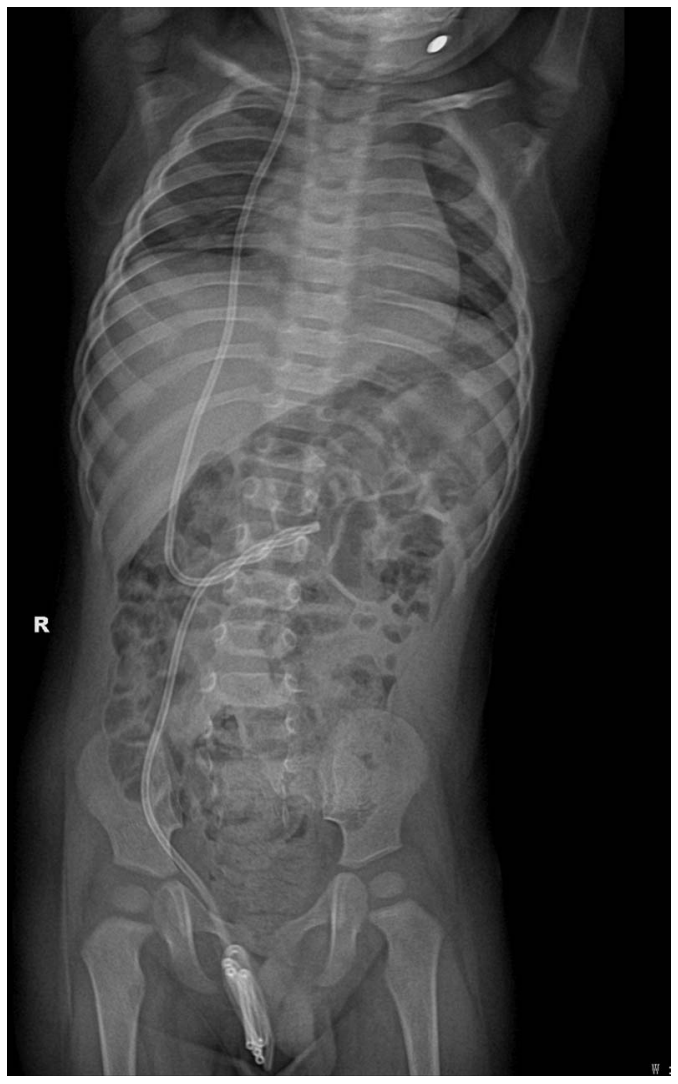

Figure 1 Frontal radiograph of the chest and abdomen showed shunt tube in the abdomen which was twisted and kinked in its mid portion and its distal end coiled in the right scrotum. include shunt migration. Migration of the distal segment of VP shunt into the abdominal wall, hollow viscus, vagina, scrotum, bladder and mediastinum has been described previously. ${ }^{1}$ The incidence of distal migration of VP shunt is reported to be $10 \% .^{2}$ In a study of 108 children with VP shunt, the incidence of scrotal migration was found to be $3.7 \% .^{3}$

Processus vaginalis remains patent in $90 \%$ of males at birth, $50-60 \%$ at 1 year, $40 \%$ in $2-16$ years and $15-30 \%$ in adulthood. ${ }^{4}$ Smaller peritoneal cavity in paediatric patients, which is distended due to draining cerebrospinal fluid, prevents the obliteration of the processus vaginalis and facilitates migration of the VP shunt into the scrotum. ${ }^{5}$

Scrotal migration of the VP shunt can cause secondary hydrocoele and shunt malfunction leading to worsening of the hydrocephalus. Bilateral herniotomy with repositioning of the shunt tube is the treatment of choice.

\section{Learning points}

- Possibility of migration of shunt should be suspected in case of scrotal swelling in children with ventriculoperitoneal shunts.

- Plain radiograph is a simple screening modality to assess the position of the ventriculoperitoneal shunt.

- Bilateral herniotomy with repositioning of the shunt tube is the treatment of choice.

\section{Competing interests None.}

Patient consent Obtained.

Provenance and peer review Not commissioned; externally pee reviewed.

\section{REFERENCES}

1 Mohammadi A, Hedayatiasl A, Ghasemi-Rad M. Scrotal migration of a ventriculoperitoneal shunt: a case report and review of literature. Med Ultrason 2012;14:158-60.

2 Kast J, Duong D, Nowzari F, et al. Time-related patterns of ventricular shunt failure. Childs Nerv Syst 1994;10:524-8.

3 Oktem IS, Akdemir H, Koç K, et al. Migration of abdominal catheter of ventriculoperitoneal shunt into the scrotum. Acta Neurochir (Wien) 1998;140:167-70.

4 Rowe MI, Copelson LW, Clatworthy HW. The patent processus vaginalis and inguinal hernia. J Pediatr Surg 1969;4:102-7.

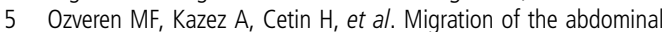
catheter of a ventriculoperitoneal shunt into the scrotum - case report. Neurol Med Chir (Tokyo) 1999;39:313-15. 


\section{Images in...}

Copyright 2014 BMJ Publishing Group. All rights reserved. For permission to reuse any of this content visit http://group.bmj.com/group/rights-licensing/permissions.

BMJ Case Report Fellows may re-use this article for personal use and teaching without any further permission.

Become a Fellow of BMJ Case Reports today and you can:

- Submit as many cases as you like

- Enjoy fast sympathetic peer review and rapid publication of accepted articles

- Access all the published articles

- Re-use any of the published material for personal use and teaching without further permission

For information on Institutional Fellowships contact consortiasales@bmjgroup.com

Visit casereports.bmj.com for more articles like this and to become a Fellow 